\title{
Climate change and Cyperaceae
}

Book or Report Section

Published Version

Simpson, D. A., Yesson, C., Culham, A., Couch, C. A. and Muasya, A. M. (2011) Climate change and Cyperaceae. In: Hodkinson, T., Jones, M., Waldren, S. and Parnell, J. (eds.) Climate change, ecology and systematics. Cambridge University Press, pp. 439-456. ISBN 9780521766098 (Chapter 19) Available at https://centaur.reading.ac.uk/20419/

It is advisable to refer to the publisher's version if you intend to cite from the work. See Guidance on citing.

Publisher: Cambridge University Press

All outputs in CentAUR are protected by Intellectual Property Rights law, including copyright law. Copyright and IPR is retained by the creators or other copyright holders. Terms and conditions for use of this material are defined in the End User Agreement.

\section{www.reading.ac.uk/centaur}

\section{CentAUR}

Central Archive at the University of Reading

Reading's research outputs online 


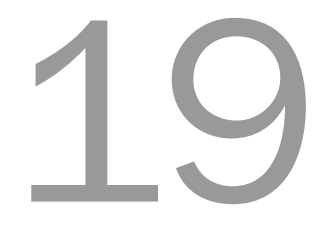

\title{
Climate change and Cyperaceae
}

\author{
D. A. Simpson \\ Royal Botanic Gardens, Kew, UK \\ C. Yesson \\ Institute of Zoology, Zoological Society of London, UK \\ A. Culham \\ School of Biological Sciences and The Walker Institute for Climate Change, \\ University of Reading, UK \\ C. A. Couch \\ Royal Botanic Gardens, Kew, UK \\ A. M. Muasya \\ Department of Botany, University of Cape Town, South Africa
}

Climate Change, Ecology and Systematics, ed. Trevor R. Hodkinson, Michael B. Jones, Stephen Waldren and John A. N. Parnell. Published by Cambridge University Press.

(C) The Systematics Association 2011. 


\section{Abstract}

Cyperaceae (sedges) are a monocotyledenous angiosperm plant family with over 5300 species. Despite their global importance, few, if any, climate change studies have been carried out on, or with, Cyperaceae. However, they may be a model family on which to base such work. They are of economic, ethnobotanical, conservation and environmental importance, and a wide range of resources for Cyperaceae is available. Examples are given of where Cyperaceae may win or lose in the climate change stakes. Taxa with $\mathrm{C}_{4}$ photosynthetic pathways, such as Cyperus rotundus ('the world's worst weed'), C. longus and members of Cyperus sect. Arenarii, are potential winners that could considerably extend their distributions. Niche modelling results are presented showing the predicted areas of climatic suitability for C. rotundus (globally) and C. longus (British Isles) in 2050. Furthermore, historical distribution data are presented that show the northward range expansion of $C$. longus in Britain during the last 100 years. The chapter highlights the threat of climate change to endemic taxa with restricted distributions, such as Carex spp., Isolepis spp., Khaosokia caricoides and Mapania spp. These appear particularly vulnerable, although, as yet, there is no direct evidence of climate change threatening or eliminating taxa.

\subsection{Introduction}

Cyperaceae (sedges) are a monocotyledenous angiosperm plant family with 106 genera and 5387 species (Govaerts et al., 2007). They are placed in the order Poales and have a superficial similarity to Poaceae (grasses). Both families have much reduced flowers and are primarily wind-pollinated. Phylogenetic studies using DNA sequencing show that Cyperaceae have a sister-group relationship with Juncaceae (rushes) (Muasya et al., 1998; Chase et al., 2006) while Poaceae are more distantly related. Grasses include some of the world's most impor tant crops, such as rice (Oryza sativa L.), wheat (Triticum L. spp.) and maize (Zea mays L.). Grasses and sedges combined include some of the world's worst weeds, such as alang-alang (Imperata cylindrica (L.) Beauv.; Poaceae), purple nutsedge (Cyperus rotundus L.; Cyperaceae) and yellow nutsedge (Cyperus esculentus L.; Cyperaceae), giving the Poales top place in the league of economic plants. Despite their global importance, few, if any, climate change studies have been carried out on, or with, Cyperaceae. The aim of this chapter is to demonstrate that Cyperaceae may be a model family on which to base climate change work, and to give some examples of where Cyperaceae may win or lose in the climate change stakes. 


\subsection{Why are Cyperaceae important?}

Cyperaceae are the seventh largest family in the angiosperms and third largest in the monocotyledons, so there is a wide range of material from which to choose for study. They are more or less cosmopolitan in distribution and are absent only from the Antarctic mainland. They occur through a wide range of altitudes from sea level up to $5000 \mathrm{~m}$ in the Himalayas, and are present in a broad range of habitats, from high Arctic tundra through to tropical forest, and to seasonally wet grasslands. They can be major or even dominant components of many plant communities. For example, in the UK, many mire, heath and wetland communities recognised by the National Vegetation Classification (Rodwell, 2006) have Cyperaceae as key taxa, such as Carex elata swamp and Scirpus cespitosus Eriophorum vaginatum blanket mire (Rodwell, 1991, 1995), while in East Africa, the well-known papyrus (Cyperus papyrus L.) can totally dominate the margins of lakes and wetlands forming an impenetrable, floating mass of plants (Haines and Lye, 1983).

Cyperaceae have significant economic and ethnobotanical importance. Nearly $10 \%$ of the family is put to use by humans (Simpson and Inglis, 2001; Simpson, 2008) with the focus of use in the tropics. They can make an important contribution to local and regional economies. For example, Actinoscirpus grossus (L.f) Goetgh. and D. A. Simpson and Cyperus corymbosus L. have been major contributors to the rural economy of northeastern Thailand, where they are cultivated and woven into matting and basketry (Simpson, 1992), although recent personal observations by the first author suggest this is now in decline. Cyperus corymbosus is similarly used in south India (Amalraj, 1991).

Cyperaceae also have conservation and environmental importance. They are major or even dominant components of wetland habitats. Wetland species attract wildlife by providing food and shelter, and the decline of sedge species within these types of habitats is a useful indicator of potential habitat damage. In terms of ecosystem services they can play a particular role in the maintenance and improvement of water quality. Constructed wetlands, artificial marshes or swamps created for anthropogenic discharge such as wastewater, stormwater, runoff or sewage treatment in various parts of the world have included Cyperaceae species such as Baumea articulata (R. Br.) S. T. Blake, Bolboschoenus fluviatilis (Torr.) Soják, Cyperus involucratus Rottb. and Schoenoplectus californicus (C. A. Mey.) Soják, amongst others. For example, water treatments using Cyperaceae have demonstrated up to $92 \%$ removal of total nitrogen (Tanner, 1996) and significant sequestration of metals such as copper (Murray-Gulde et al., 2005). 


\subsection{Resources available}

Resources available on the family are wide-ranging. There is a large number of specimens of Cyperaceae available in the world's herbaria. A particularly comprehensive collection is available at the Royal Botanic Gardens, Kew, UK, where research on Cyperaceae has been undertaken since the 1880s and the herbarium has $c$. 120000 specimens covering all genera and nearly all species (www.kew.org/science/directory/teams/MonocotsII/background.html). Large and important herbarium collections of Cyperaceae are also available at the New York Botanical Garden (USA), Missouri Botanical Garden (USA), Muséum National d'Histoire Naturelle (France), Institute of Botany, Chinese Academy of Sciences (China) and the Royal Botanic Gardens Sydney (Australia), amongst many others. Overall, these build into a vast databank of information about Cyperaceae, which can increasingly be accessed online, such as via the Herbarium Catalogue at Kew (http://apps.kew.org/herbcat/).

Other resources based on herbarium specimens include the World Checklist of Cyperaceae (Govaerts et al., 2007), a listing of all accepted names of taxa and synonyms in Cyperaceae with distributional information down to Biodiversity Information Standards Level 3 of the International Working Group on Taxonomic Databases for Plant Sciences (TDWG - Brummitt et al., 2001). Checklists for Level 3 geographical units can be built in the online version (Govaerts et al., 2009). Distribution data from herbarium specimens could be important in understanding past and present distributions of Cyperaceae, which in turn may be linked to climate change data.

Preliminary conservation status assessments for species, using the International Union for Conservation of Nature categories and criteria (IUCN, 2001), can be made using distribution data. This is an exercise which, to date, has hardly been undertaken for Cyperaceae, but which is urgently needed. For example, we have completed assessments for Thailand using CATS GIS software tools (Willis et al., 2003 - www.kew.org/gis/projects/cats), which show that 40 species out of a total of 250 in Thailand are in the Vulnerable (VU), Endangered (EN) or Critically Endangered (CR) categories (C. A. Couch and D. A. Simpson, unpublished). Another 15 are in the Near Threatened (NT) category. Such assessments serve to highlight taxa that may be particularly vulnerable to climate change and where an accelerated programme of conservation assessment is required.

An understanding of the classification of Cyperaceae and relationships between the taxa underpins any biological work on the family. Classifications are traditionally based on the use of morphological data to delimit groups. However, one of the inherent problems of using such data in Cyperaceae is their reduced 
structure, especially in the inflorescence, which makes it difficult to work out homologies within characters. Many earlier workers also saw evolution in the family as a linear series of reductions in floral complexity. This has often followed the pattern of treating forest-dwelling genera with a complex floral structure (e.g. Scirpodendron and Mapania) as 'primitive', and genera of predominantly open habitats with a simplified structure, such as Carex, as 'advanced' (Kern, 1974). DNA-based phylogenetic trees have become available over the past decade or so (Muasya et al., 1998, 2000, 2009; Simpson et al., 2007); these have helped to shed light on a number of anomalies, and different patterns of relationship are now coming to light. For example, there is strong evidence that Cyperaceae comprises just two subfamilies, Cyperoideae and Mapanioideae (Simpson et al., 2007; Muasya et al., 2009), rather than the four (Caricoideae, Cyperoideae, Mapanioideae and Sclerioideae) previously recognised (Bruhl, 1995; Goetghebeur, 1998). We now also understand that Carex, the largest genus in Cyperaceae, together with allied genera which, for many years, were placed as an isolated 'advanced group' in their own subfamily or even separate family Kobresiaceae (Gilly, 1952), are closely related to tribe Scirpeae. This relationship was hinted at from a morphological standpoint by Dahlgren et al. (1985) and is clearly supported by molecular data (Simpson et al., 2007).

While some problems may have been resolved through molecular work, others have arisen, such as the placement of Cyperus species with either the $\mathrm{C}_{3}$ and $\mathrm{C}_{4}$ photosynthetic pathway into different clades despite the lack of unambiguous characters separating the $\mathrm{C}_{3}$ and $\mathrm{C}_{4}$ species. Despite progress in the phylogenetics and taxonomy of Cyperaceae at tribal level, there is still much more work to do at lower taxonomic ranks. Preliminary attempts at dating phylogenetic trees that include Cyperaceae have also been made (Bremer, 2002) and a recent study including most lineages of Cyperaceae show a stem age of the family at about 87 million years ago (Besnard et al., 2009). The recent discovery of Volkeria messelensis S. Y. Smith, Collinson, D. A. Simpson, Rudall, Marone and Stampanone (Smith et al., 2009), a 48-million-year-old fossil mapanioid sedge, should help to give more accuracy to the date estimations of major Cyperaceae clades.

Finally, there is a range of expertise in the family based in many parts of the world. Cyperologists have demonstrated an excellent level of cooperation over recent years. Cyperaceae symposia have been held at the Monocots II, III and IV conferences in 1998, 2003 and 2008, respectively, and at the International Botanical Congress in Vienna, Austria, in 2005. The Sedges 2002 Symposium was held at Delaware State University in the USA in 2002 (Naczi and Ford, 2008). These regular gatherings have ensured that our understanding of the family has advanced and have been the impetus for the molecular phylogenetic work indicated above (e.g. Muasya et al., 2000, 2009; Simpson et al., 2007). 


\subsection{Climate change: examples of potential winners and losers in Cyperaceae}

\subsubsection{Potential winner: $C_{4}$ photosynthetic pathway and Cyperus rotundus - the world's worst weed}

Two patterns of vegetative anatomy are present in Cyperaceae, one with radiate chlorenchyma and green chlorenchymatous sheaths within the vascular bundles, the other with non-radiate chlorenchyma and vascular bundles surrounded by a sheath of colourless cells (Bruhl and Wilson, 2007). These differences are correlated with the presence, in the former, of the $\mathrm{C}_{4}$ photosynthetic pathway. Estimates of the number of Cyperaceae species with the $\mathrm{C}_{4}$ pathway vary between $27 \%$ (Sage et al., 1999) and $34 \%$ (Bruhl and Wilson, 2007). Within the family the $\mathrm{C}_{4}$ pathway has evolved at least four times (Soros and Bruhl, 2000; Christin et al., 2008), giving rise to the 'chlorocyperoid' ( $\mathrm{C}_{4}$ members of Cyperus and allied genera), 'eleocharoid' (Eleocharis), 'fimbristyloid' (Fimbristylis and allied genera) and 'rhynchosporoid' (Rhynchospora) anatomical types.

$\mathrm{C}_{4}$ plants can have an advantage over $\mathrm{C}_{3}$ plants under conditions of water stress, high temperatures and high light intensity (Hopkins and Hüner, 2004; Bryson and Carter, 2008; Bouchenak-Khelladi and Hodkinson, Chapter 7); thus they are better adapted to hotter, drier climates. Genera of Cyperaceae with the $\mathrm{C}_{4}$ pathway are particularly found in seasonally wet or drought-prone habitats within the tropics, exhibiting the greatest species diversity within these regions. This is exemplified by Cyperus, which has the greatest species diversity in eastern and southern Africa, regions which are frequently prone to periodic drought, with associated high temperature and light intensity.

Cyperaceae contain a number of taxa that are highly aggressive and potent weeds. Terry (2001) estimated this number to be 230 species, while Simpson (2008) categorised 168. Among the most widespread and competitive are Cyperus difformis L., C. esculentus, C. iria L., C. haspan L., C. rotundus and Fimbristylis dichotoma (L.) Vahl. All are pantropical and cause very serious problems for agriculture and horticulture (Terry, 2001; Bryson and Carter, 2008; Simpson, 2008) throughout their ranges. Four of these species are $\mathrm{C}_{4}:$ C. esculentus, C. iria, $C$. rotundus and $F$. dichotoma.

Cyperus rotundus is the most troublesome and has often been called the world's worst weed (Holm et al., 1977; Terry, 2001), because it causes major problems in 52 crops in 92 countries, mostly in the tropics and subtropics (Parsons and Cuthbertson, 1992; Bromilow, 1995). It spreads by underground rhizomes and tubers; there may be up to 500 plants per $\mathrm{m}^{2}$ and there may be 53000 tubers per $\mathrm{m}^{3}$ of soil (Parsons and Cuthbertson, 1992). Indeed, so successful does this method of perennation appear to be that $C$. rotundus seldom sets fruit (Kern, 1974). It is 
resistant to many common herbicides and costs the world millions of dollars per year in lost production and control measures (Tuor and Froud-Williams, 2002).

With climate change, the potential for C. rotundus to move into new regions, especially those likely to become hotter and drier, is a serious cause for concern. We undertook a preliminary investigation of this potential by developing a niche model to determine areas climatically suitable for C. rotundus in 2050 . The model was built with openModeller v.1.0.7 (http://openmodeller.sourceforge.net) using the 'GARP with best subsets - new openModeller implementation' algorithm, with the default settings (AUC $=0.83$ ). Distribution data for $C$. rotundus were gathered from digitised herbarium records accessed from the Global Biodiversity Information Facility (www.gbif.org). Climate data were as used by Yesson and Culham (2006; Chapter 12) with present-day climate data from the Climate Research Unit (CRU) CL1 data set and future climate data based on the Hadley A2c model. The future model accounts for a moderate increase in carbon dioxide $\left(\mathrm{CO}_{2}\right)$.

Figure 19.1A shows current climatic conditions favourable to C. rotundus. There is a particular concentration in tropical, subtropical and warm temperate regions, especially where there is a hot dry period during the year, which would favour plants with the $\mathrm{C}_{4}$ pathway. Figure 19.1B shows climatic conditions predicted for 2050. The overall pattern is similar, with a focus on present-day tropical to warm temperate regions. However, there are some notable differences. For example, conditions become more favourable further north in Europe up to the English Channel and North Sea coasts, with a possible spread into southern England. This would match with modelled change to hotter drier summers in northern Europe. Cyperus rotundus could therefore present a threat to agriculture in parts of Europe where it does not currently occur or where it is non-competitive with crops at the present time. There is also some predicted spread northwards in the USA and around the southern coasts of Australia. In contrast, conditions are predicted to become less favourable in other places, notably a large swathe of South America south of the Amazon basin, much of India, parts of Thailand and Indochina, and much of inland Australia.

These data must be treated with caution, as the distribution points focus only on data currently available through GBIF and are not an accurate representation of the worldwide distribution of $C$. rotundus (see Culham and Yesson, Chapter 10); nor are the models able to account fully for the change in competitiveness of $\mathrm{C}_{4}$ and $\mathrm{C}_{3}$ plants in elevated $\mathrm{CO}_{2}$ conditions, where the physiological advantage of $\mathrm{C}_{4}$ photosynthesis may be less than under current conditions.

\subsubsection{Potential winner: Cyperus longus $-\mathrm{a}_{\mathbf{4}}$ species in the UK}

Cyperus longus L. is widely distributed from Europe to southern Africa, in the Middle East and in parts of Asia. It is present in the UK at the northern limits of its range (Collins et al., 1988). It is found in marshy pond margins, often near the 


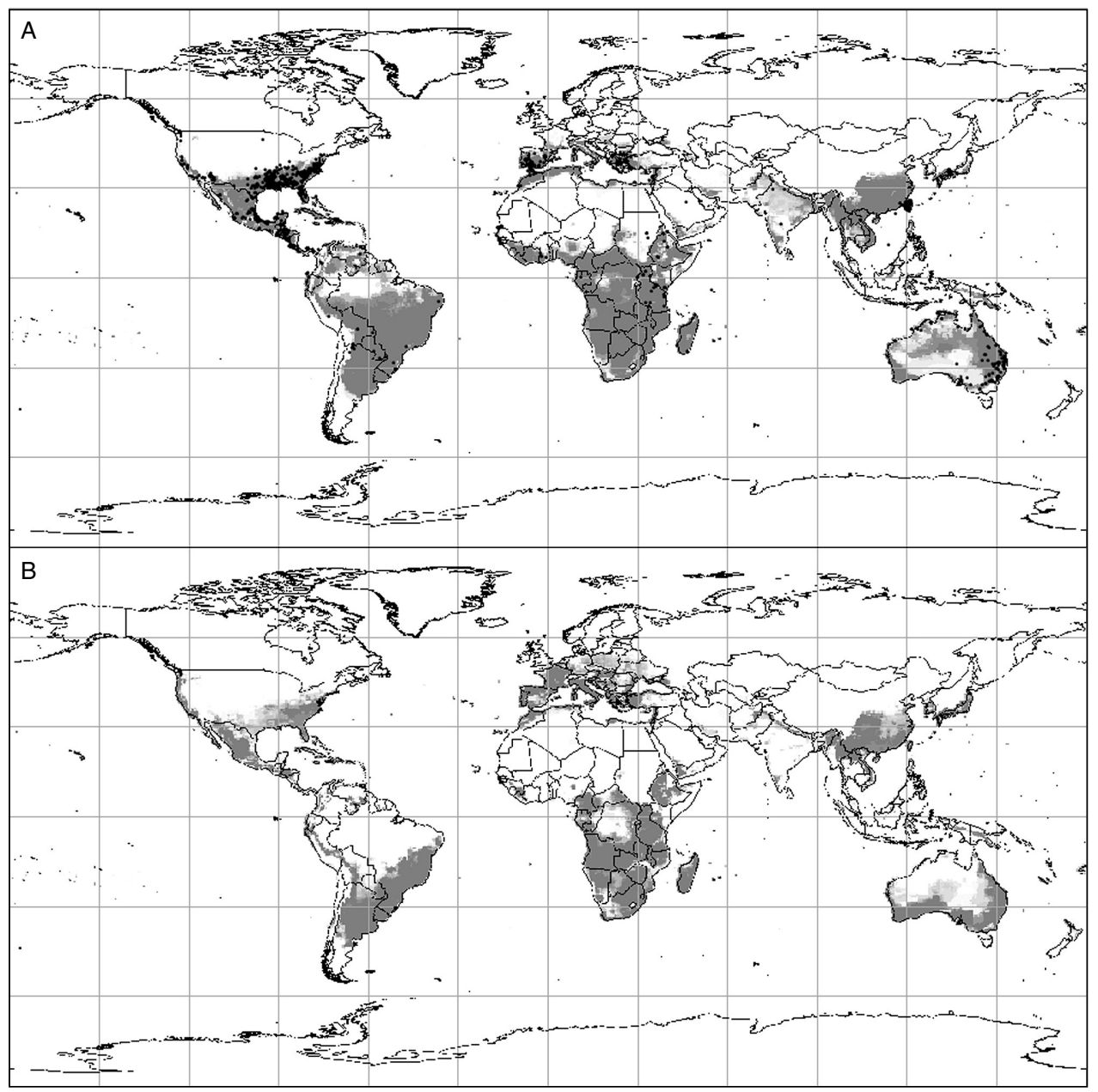

Figure 19.1 Areas climatically suitable for Cyperus rotundus, as determined by a GARP niche model within (A) present-day climate and (B) predicted climate for 2050. Presentday distribution suitability based on the CRU CL1 model and future distribution based on the Hadley A2c model. Darker shaded areas indicate higher suitability. Black dots show current distribution points. Global climate data are of 0.25 degree resolution and the overlying grid is of 30 degree squares.

coast, but in recent years it has become established at inland sites, where it can show vigorous rhizome growth (Jermy et al., 2007). Cyperus longus is one of the few native British $\mathrm{C}_{4}$ species, and the physiology of $C$. longus under low-temperature conditions has been the subject of a number of studies (e.g. Jones et al., 1981; Collins and Jones, 1986, 1988). Such studies suggest that leaf extension is very slow at lower temperatures, which restricts leaf canopy development and is a factor in 
determining the outcome of competition between $C$. longus and other species. However, small differences in relative growth rate at temperatures of $10-30{ }^{\circ} \mathrm{C}$ result in large differences in foliage area between lower and higher temperatures, suggesting that the plant can better compete at higher temperatures.

Figure 19.2 shows the distribution of $C$. longus in the UK from pre-1930 to the present day. Before 1930 the species was confined to southern England, with one record as far north as Lincolnshire. In subsequent years there was an increase in the number of records together with a distributional spread northwards. By the 1970-86 period it had reached Northumberland, and in the 1987-99 period there were two records from Scotland. The most recent map (2000+) shows one record from Scotland and a number of records from northeastern and northwestern England, so it appears to be firmly established in these regions.

The northward spread is coincident with an increase in the mean annual temperature across the UK. For pre-1930 the mean annual temperature was $c .8 .5^{\circ} \mathrm{C}$, for the $1930-69$ period it was $c .9{ }^{\circ} \mathrm{C}$ and for $2000+$ it was $c .9 .5{ }^{\circ} \mathrm{C}$ (Hulme et al., 2002). We also prepared a GARP niche model for C. longus in the UK and Ireland to show areas of suitability for the growth of this species under present-day conditions and predicted conditions in 2050, again using data based on the Hadley A2c model (Fig 19.3). The data show that, at the present time, conditions in the UK are highly suitable up to $c .55^{\circ} \mathrm{N}$, whereas by 2050 there is a shift to $c .56^{\circ} \mathrm{N}$, with large areas of northern England and southern Scotland becoming highly suitable.

At this stage it is uncertain whether the shift of $C$. longus further north can be directly attributable to the increase in temperature; further studies are necessary. The situation is made even more complex by the fact that most of the recent records are introductions rather than natural occurrences (Jermy et al., 2007). Cyperus longus is frequently grown in gardens as a bog or pond-side plant, and it is possible that many of these records represent material of garden origin. Whatever the form of spread, it is nevertheless apparent that the plant is now occurring much further north than it has done in the past. If this $\mathrm{C}_{4}$ species can spread in such a way then the possibilities of other, more pernicious taxa, such as C. rotundus and C. esculentus, getting a foothold in the UK and Ireland would seem to be increasing.

\subsubsection{Potential winner: Cyperus sect. Arenarii}

Cyperus sect. Arenarii Kunth ex Jaub. and Spach. is a group of 25 species (e.g. Cyperus conglomeratus Rottb., C. crassipes Vahl - Väre and Kukkonen, 2005) distributed from the Mediterranean region to India and Sri Lanka and throughout Africa. Many of the species are psammophytic, being adapted to hot, dry conditions, especially deserts and sandy areas on coasts. They have a number of characteristics that help to reduce water loss, including a thick cuticle all over the plant, bluish-green coloration and narrow, canaliculate leaves. In common with other Cyperaceae they have a reduced inflorescence structure. A characteristic feature 


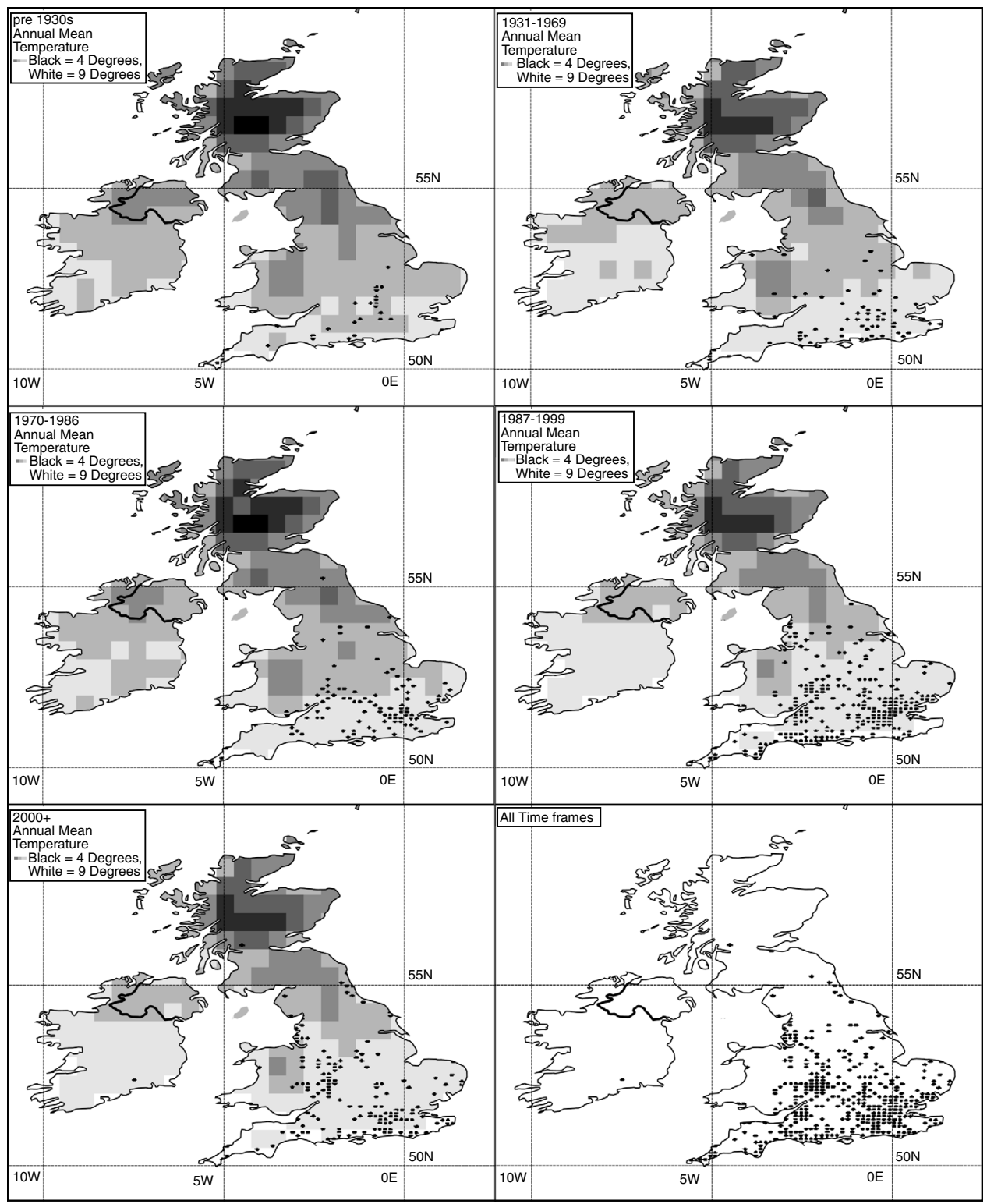

Figure 19.2 Changes in the UK distribution of Cyperus longus over the past century. Distribution data from the Botanical Society of the British Isles (www.bsbimaps.org. uk/atlas). The 'All Timeframes' map summarises all the distribution points. Gridded shading indicates annual mean temperature data for the relevant time period (except for $2000+$, where data are not available, and therefore 1990s data are shown). Shading is in increments of $1^{\circ} \mathrm{C}$ (black $=4{ }^{\circ} \mathrm{C}$, white $=9^{\circ} \mathrm{C}$ ). Data taken from the CRU TS 2.1 global time series data sets (Mitchell and Jones, 2005). Summary of all distribution data shown in all timeframes. 


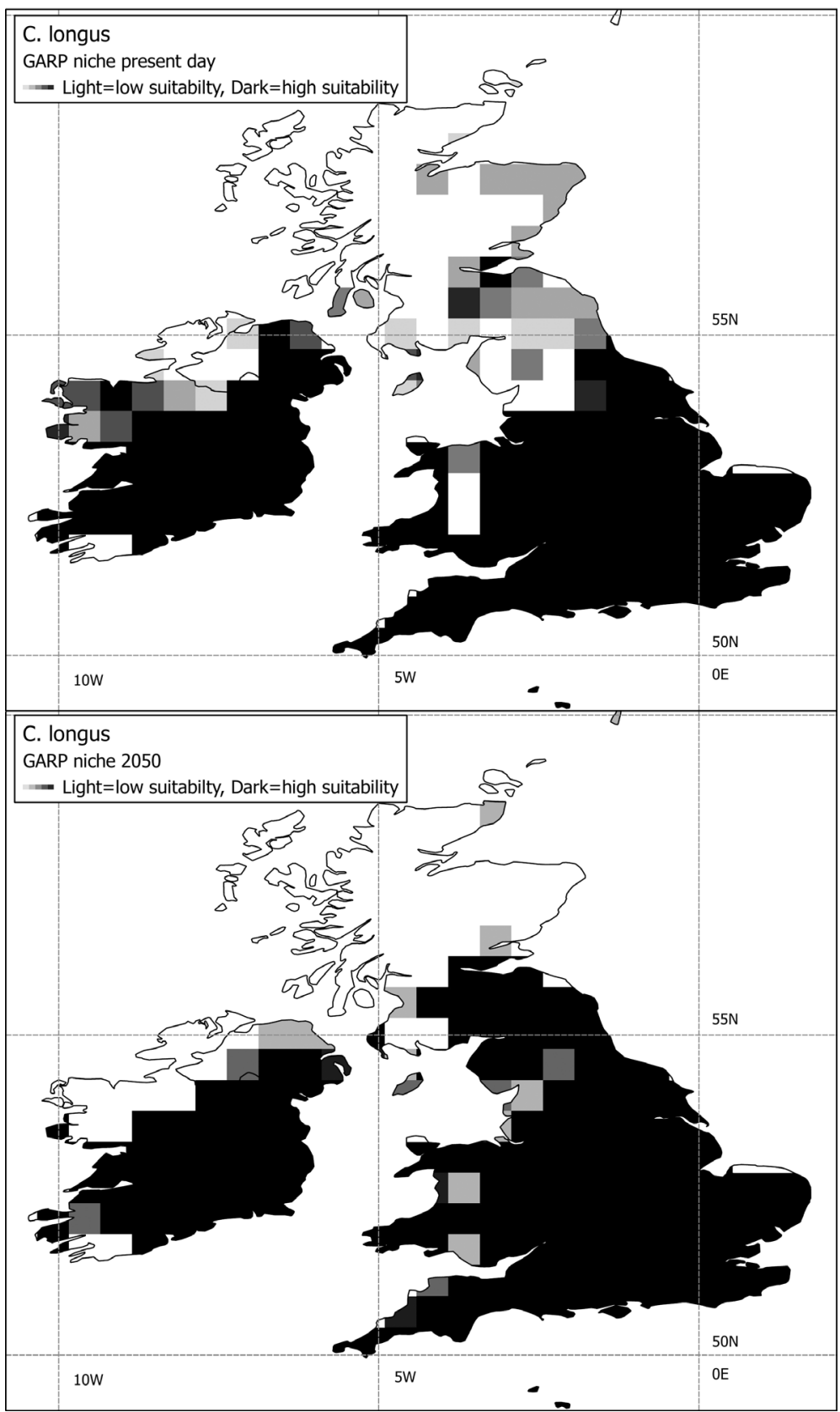

Figure 19.3 Areas climatically suitable for Cyperus longus in the UK and Ireland. Areas determined by a GARP niche model within present-day climate and predicted climate for 2050, trained with distribution data from GBIF using present-day climate data. This model was projected into the predicted climate for 2050 (scenario A2c). Darker shaded areas indicate higher suitability. 
of the perennial species is the long creeping rhizome, which is often densely tomentose. The rhizome may be deeply buried in sand, and the tomentum probably helps to reduce water loss and aid survival in conditions of extreme aridity (Väre and Kukkonen, 2005). Väre and Kukkonen (2005) noted that some species are able to penetrate into the most arid parts of the Sahara where little else survives. The four taxa analysed to date for photosynthetic pathway are all $\mathrm{C}_{4}$. All members of this group would probably show range extensions if hotter, drier conditions began to prevail outside their current distribution, for example in parts of southern Europe. Interestingly, some members of the group, especially C. conglomeratus, are recognised for their sand-binding ability, and are used for that purpose in parts of the Middle East (Simpson and Inglis, 2001). There could be an increasing use of this and other related species in areas that become increasingly prone to desertification through climate change. A niche modelling approach, based on the distribution data of the taxa in Cyperus sect. Arenarii, would again be a worthwhile exercise to predict future distribution patterns.

\subsubsection{Potential losers}

There is a wide range of taxa that may be under threat from climate change. Endemic taxa with restricted distributions appear particularly vulnerable, and there are numerous examples of such taxa among the Cyperaceae. It should be noted that, at this stage, we have no direct evidence of climate change threatening or eliminating taxa, and the examples given below are intended to highlight potential problems.

Mapania is a pantropical genus of $c$. 80 species and is a characteristic group of the herb layer of ever-wet tropical forests. Simpson (1992) noted that they occur where little light penetrates through the forest canopy, mostly 'in areas where the soil is particularly damp, muddy or peaty or in swampy depressions or by the side of pools or streams'. Many species are local endemics with highly restricted distributions; just a few species are widespread: for example Mapania cuspidata (Miq.) Uttien, which occurs throughout Southeast Asia. Whether widespread or restricted in distribution they are seldom abundant in any one locality. Engelbrecht et al. (2007) observed that drought has a limiting effect on tropical plant distributions and that in tropical rainforests global warming could result in loss of diversity and perhaps species extinction. Drier conditions could, therefore, accelerate the decline, and possible extinction, of many Mapania species throughout the tropics. Of course, other factors could be involved. Simpson (1992) noted that some of the local species may already be extinct through forest clearance, as they seem unable to tolerate higher light and lower humidity levels. The survival of Mapania spp. may also depend on factors such as dispersal ability of the species and niche suitability, but it is not yet known how well Mapania could migrate with changing climate or adapt to new conditions. Further work is necessary. 
Khaosokia caricoides D. A. Simpson, Chayam. and J. Parn. was first discovered in Khao Sok National Park, Surat Thani Province, Thailand, in 2001 (Simpson et al., 2005). So far it has only been recorded from one locality, and its habitat (crevices on sunny limestone cliffs) is highly unusual for Cyperaceae. It occurs in an area once covered by rainforest which was flooded to produce a reservoir. Prior to that the species would have been inaccessible, growing high up on the limestone cliffs. However, the formation of the reservoir has allowed the plant to be reached by boat. It could be present in similar limestone habitats elsewhere in Thailand and Malaysia that are so far inaccessible to collectors. Such habitats are already threatened by human activity, especially limestone extraction. Human activity is unlikely to threaten the known locality for $K$. caricoides, because the reservoir offers protection, but other populations, should they exist, could be put under pressure.

Figure 19.4 shows current and predicted annual mean temperatures for Thailand based on the same climate models used in the niche model for C. rotun$d u s$, above. The locality for $K$. caricoides is indicated by ' $\mathrm{A}$ '. The data suggest that

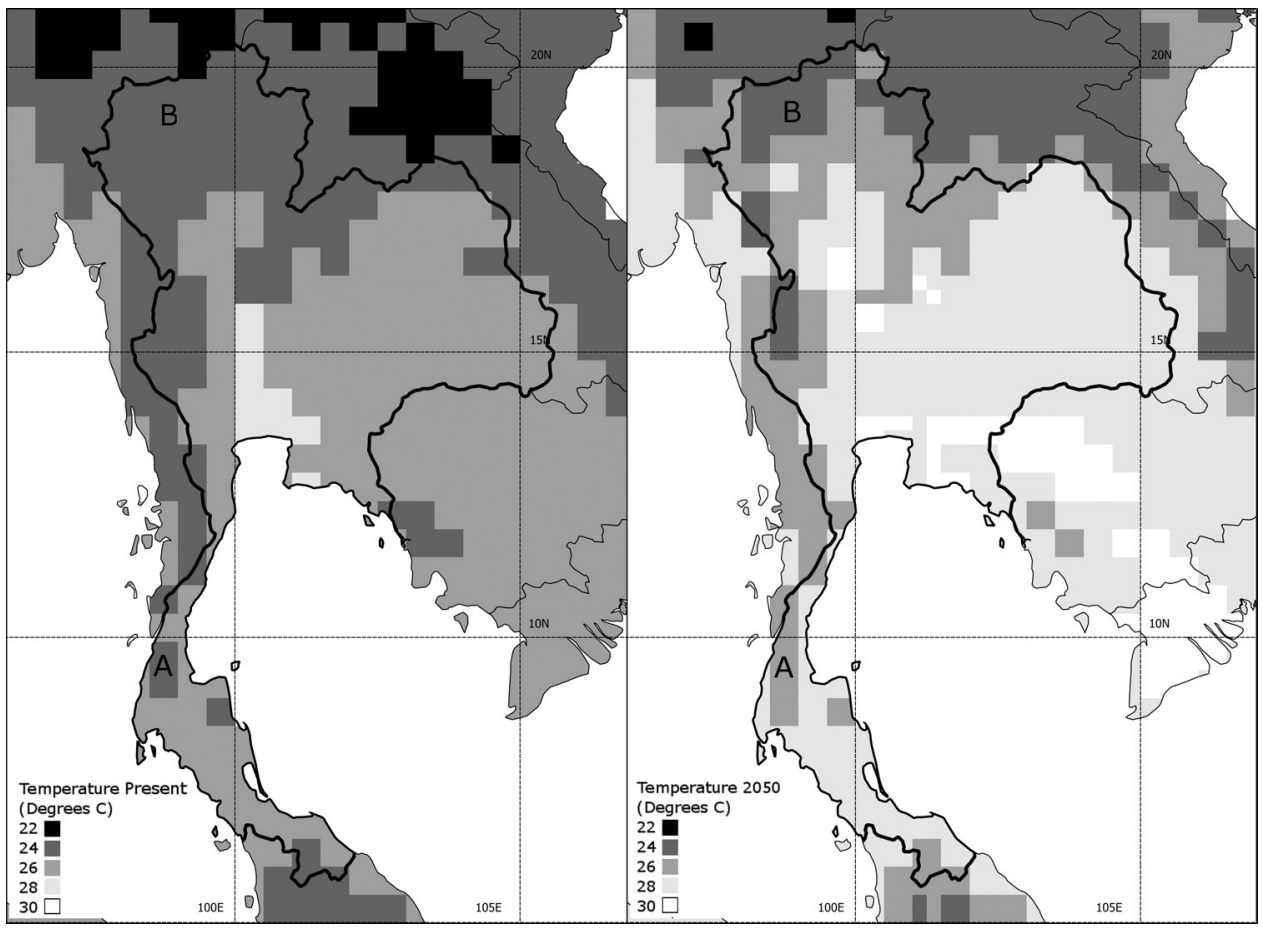

Figure 19.4 Annual mean temperature for Thailand. Climate data for present and future predictions as for Fig 19.1. A, only known locality of Khaosokia caricoides. B, Carex phyllocaula, endemic to Doi Chiang Dao Mountain. 
temperatures will increase at this locality by $2{ }^{\circ} \mathrm{C}$ by 2050 . Yusuf and Francisco (2009) indicated that Surat Thani is one of the provinces in Thailand vulnerable to the effects of multiple climate change hazards including drought and flood, while Boonprakrob and Hattirat (2006) suggested that Khao Sok National Park will be adversely affected by climate change, based on the UK 89 climate model. Moreover, neighbouring Krabi Province will be affected by a $10 \%$ decrease in total annual rainfall by 2033 (WWF, 2008) due to a predicted shortening of the annual monsoon season over peninusular Thailand by four weeks. Unfortunately we know next to nothing about the ecological requirements of $K$. caricoides, but, as far as we can tell, rain falling directly onto the cliffs, together with any associated runoff, is the only way the plant obtains water. Should the climate become drier at Khao Sok, K. caricoides could be affected by the reduced amount of rainfall it would receive. Simpson et al. (2005) also demonstrated it to be a $\mathrm{C}_{3}$ species, which suggests it could be less tolerant of hotter, drier conditions. Once again, further studies are necessary.

Many species of the large and cosmopolitan genus Carex have restricted distributions. Several species in Thailand have been shown to have an IUCN conservation status of VU to CR (C. A. Couch and D. A. Simpson, unpublished data). One such example is Carex phyllocaula Nelmes, which is classified as EN (based on Area of Occupancy - IUCN, 2001) and is endemic to Doi Chiang Dao, a mountain in northern Thailand. It is found in thickets and open grassy ground at altitudes of $1500-2100 \mathrm{~m}$ and is only known from a few specimens. Figure 19.4 shows the locality for C. phyllocaula, marked as 'B' on the map. Present-day and predicted temperatures are the same. However, there is evidence for a predicted long-term decrease in September rainfall over the Indochina peninsula, which includes northern Thailand (Takahashi et al., 2008). This may have a longer-term effect on the vegetation on the mountain, and suitable habitat for C. phyllocaula may be reduced, affecting the plant's survival. Other rare species in Thailand could be similarly affected.

Other mountain endemic species are known worldwide. For example, three species of Isolepis R. Br., I. keniaensis Lye, I. kilimanjarica R. W. Haines and Lye and $I$. ruwenzoriensis R. W. Haines and Lye are respectively endemic to Mount Kenya, Mount Kilimanjaro and Mount Ruwenzori in East Africa (Haines and Lye, 1983; Muasya and Simpson, 2002). They only occur at high altitudes (3650-4350 m) and are known from just one specimen each, an indication of their rarity. All are also reported to occur in alpine bogs. Climate change, especially changes in rainfall pattern and/or higher temperatures, could again affect the composition of the vegetation at these altitudes, perhaps by changing species composition or encouraging scrub or forest to move to higher altitudes in the mountains. 


\subsection{Where next?}

There is much work to be done in order to obtain a comprehensive picture of how Cyperaceae will be affected by climate change. Indeed, we are just at the start of gaining an understanding in this area. We must focus on the distributions of taxa and their controlling environmental variables. Some distributions, especially for taxa that are common weeds, are well understood and there are many records available, either in the literature or from herbarium specimens. Much less is known about those with restricted distributions; are they truly rare, or is their perceived rarity an artefact due to insufficient collecting? We also need to consider linking past and present distributions to different climate change models to see how the taxa would be affected under various scenarios. The preliminary niche modelling work with Cyperus rotundus described above has shown the potential use of such techniques. We need a better understanding of the evolution of characters and traits to determine how taxa might respond to climate change. The occurrence of $\mathrm{C}_{3}$ and $\mathrm{C}_{4}$ photosynthesis in Cyperaceae needs particular study, as the potential for $\mathrm{C}_{4}$ species to extend their distributions and for the weedy taxa to wreak havoc on agricultural systems in temperate regions is high.

In all this work, taxonomy and systematics will play a vital role. Both will help to provide basic data about taxa, whether on characters and traits or on distributions and rarity, as well as a better understanding of the relationships between taxa and character evolution. Such research will be needed to underpin planning for agricultural systems and food supplies in Europe and around the world, for planning the conservation of biodiversity at global and local scales, and for discovering which species may have new uses in the stabilisation of soils and protection from erosion of water catchment areas.

\section{References}

Amalraj, V. A. (1991). Cultivated sedges of S. India for mat weaving industry. Journal of Economic and Taxonomic Botany, 14, 629-631.

Besnard, G., Muasya, A. M., Russier, F. et al. (2009). Phylogenomics of $\mathrm{C}_{4}$ photosynthesis in sedges (Cyperaceae): multiple appearances and genetic convergence. Molecular Biology and Evolution, 26, 1909-1919.

Boonprakrob, K. and Hattirat, S. (2006). Crisis or Opportunity: Climate
Change and Thailand.

Bangkok: Greenpeace Southeast Asia.

Bremer, K. (2002). Gondwanan evolution of the grass alliance of families (Poales). Evolution, 56, 1374-1387.

Bromilow, C. (1995). Problem Plants of South Africa. Arcadia: Briza Publications.

Bruhl, J. J. (1995). Sedge genera of the world: relationships and a new classification of Cyperaceae. 


\section{Australian Systematic Botany, $\mathbf{8}$,} 125-305.

Bruhl, J. J. and Wilson, K. (2007). Towards a comprehensive survey of $\mathrm{C}_{3}$ and $\mathrm{C}_{4}$ photosynthetic pathways in Cyperaceae. Aliso, 23, 99-148.

Brummitt, R. K., Pando, F., Hollis, S. et al. (2001). World Geographic Scheme for Recording Plant Distributions. Plant Taxonomic Database Standards No. 2, 2nd edn. Pittsburgh, PA: Hunt Institute for Botanical Documentation.

Bryson, C. T. and Carter, R. (2008).

The significance of Cyperaceae as weeds. In Sedges: Uses, Diversity, and Systematics of the Cyperaceae, ed. R. F. C. Naczi and B. A. Ford. Monographs in Systematic Botany from the Missouri Botanical Garden. St Louis, MO: Missouri Botanical Garden Press, pp. 15-101.

Chase, M. W., Fay, M. F., Devey, D. S. et al. (2006). Multigene analyses of monocot relationships: a summary. Aliso, 22, 63-75.

Christin, P. A., Salamin, N., Muasya, A. M. et al. (2008). Genetic convergence exposes determinants of Rubisco higher efficiency in $\mathrm{C}_{4}$ plants. Molecular Biology and Evolution, 25, 2361-2368.

Collins, R. P. and Jones, M. B. (1986). The seasonal pattern of growth and production of a temperate $\mathrm{C} 4$ species, Cyperus longus. Journal of Experimental Botany, 37, 1823-1835.

Collins, R. P. and Jones, M. B. (1988). The effects of temperature on leaf growth in Cyperus longus, a temperate $\mathrm{C} 4$ species. Annals of Botany, 61, 355-362.

Collins, R. P., McNally, S. F., Simpson, D. A. and Jones, M. B. (1988). Infraspecific variation of Cyperus longus $\mathrm{L}$. in Europe. New Phytologist, 110, 279-289.
Dahlgren, R. M. T., Clifford, H. T. and Yeo, P. F. (1985). The Families of the Monocotyledons. Berlin: SpringerVerlag.

Engelbrecht, B. M. J., Comita, L. S., Condit, R. et al. (2007). Drought sensitivity shapes species distribution patterns in tropical forests. Nature, 447, 80.

Gilly, G. L. (1952). Phylogenetic development of the inflorescence and generic relationships in the Kobresiaceae. Iowa State College Journal of Science, 26, 210-212.

Goetghebeur, P. (1998). Cyperaceae. In The Families and Genera of Vascular Plants 4, ed. K. Kubitzki, H. Huber, P. J. Rudall, P. S. Stevens and T. Stützel. Berlin: Springer-Verlag, pp. 141-190.

Govaerts, R., Simpson, D. A., Bruhl, J. et al. (2007). World Checklist of Cyperaceae. London: Royal Botanic Gardens, Kew.

Govaerts, R., Simpson, D. A., Bruhl, J. et al. (2009). World Checklist of Cyperaceae. London: Royal Botanic Gardens, Kew. www.kew.org/wcsp/monocots.

Haines, R. W. and Lye, K. (1983). Sedges and Rushes of East Africa. Nairobi: East African Natural History Society.

Holm, L. G., Plucknett, D. L., Pancho, J. V. and Herberger, J. P. (1977). The World's Worst Weeds. Honolulu, HI: University Press of Hawaii.

Hopkins, W. G. and Hüner, N. P. A. (2004). Introduction to Plant Physiology, 3rd edn. New York, NY: Wiley.

Hulme, M., Jenkins, G. J., Lu, X. et al. (2002). Climate Change Scenarios for the United Kingdom: the UKCIP02 Scientific Report. Norwich: Tyndall Centre for Climate Change Research, University of East Anglia.

International Union for the Conservation of Nature (I UCN) (2001). The IUCN Red List Categories and Criteria, version 
3.1. www.iucnredlist.org/technicaldocuments/categories-and-criteria.

Jermy, A. C., Simpson, D. A., Foley, M. J. Y. and Porter, M. (2007). Sedges of the British Isles, 3rd edn. BSBI Handbook 1. London: Botanical Society of the British Isles.

Jones, M. B., Hannon, G. E. and Coffey, M. D. (1981). $\mathrm{C}_{4}$ photosynthesis in Cyperus longus $\mathrm{L}$., a species occurring in temperate climates. Plant, Cell and Environment, 4, 161-168.

Kern, J. H. (1974). Cyperaceae. In Flora Malesiana, Vol. 1, ed. C. G. G. J. van Steenis. Leiden: Noordhoff, pp. 435-753.

Mitchell, T. D. and Jones, P. D. (2005). An improved method of constructing a database of monthly climate observations and associated highresolution grids. International Journal of Climatology, 25, 693-712.

Muasya, A. M. and Simpson, D. A. (2002). A revision of the genus Isolepis (Cyperaceae). Kew Bulletin, 57, 257-362.

Muasya, A. M., Simpson, D. A., Culham, A. and Chase, M. W. (1998). An assessment of suprageneric phylogeny in Cyperaceae using rbcL sequence data. Plant Systematics and Evolution, 211, 257-271.

Muasya, A. M., Bruhl, J. J., Simpson, D. A., Culham, A. and Chase, M. W. (2000). Suprageneric phylogeny of Cyperaceae. In Monocots: Systematics and Evolution, ed. K. L. Wilson and D. Morrison. Melbourne: CSIRO Publishing, pp. 593-601.

Muasya, A. M., Simpson, D. A., Verboom, G. A. et al. (2009). Phylogeny of Cyperaceae based on DNA sequence data: current progress and future prospects. Botanical Review, 75, 52-66.
Murray-Gulde, C. L., Huddleston, G. M., Garber, K. V. and Rodgers, J. H. (2005). Contributions of Schoenoplectus californicus in a constructed wetland system receiving copper contaminated wastewater. Water, Air and Soil Pollution, 163, 355-378.

Naczi, R. F. C. and Ford, B. A., eds. (2008). Sedges: Uses, Diversity, and Systematics of the Cyperaceae. St Louis, MO: Missouri Botanical Garden Press.

Parsons, W. T. and Cuthbertson, E. G. (1992). Noxious Weeds of Australia. Melbourne/Sydney: Inkata Press.

Rodwell, J. S., ed. (1991). British Plant Communities, Volume 2. Mires and Heaths. Cambridge: Cambridge University Press.

Rodwell, J. S., ed. (1995). British Plant Communities, Volume 4. Aquatic Communities, Swamps and Tallherb Fens. Cambridge: Cambridge University Press.

Rodwell, J. S. (2006). National Vegetation Classification: Users' Handbook. Peterborough: Joint Nature Conservation Committee.

Sage, R. F., Li, M. and Monson, R. K. (1999). The taxonomic distribution of $\mathrm{C}_{4}$ photosynthesis. In $C_{4}$ Plant Biology, ed. R. F. Sage and R. K. Monson. San Diego, CA: Academic Press, pp. 551-584.

Simpson, D. A. (1992). Notes on Cyperaceae in north-eastern Thailand. Cyperaceae Newsletter, 10, 10-12.

Simpson, D. A. (2008). Frosted curls to tiger nuts: ethnobotany of Cyperaceae. In Sedges: Uses, Diversity, and Systematics of the Cyperaceae. Monographs in Systematic Botany from the Missouri Botanical Garden, ed. R. F. C. Naczi and B. A. Ford. St Louis, MO: Missouri Botanical Garden Press, pp. 1-14. 
Simpson, D. A. and Inglis C. A. (2001). Cyperaceae of economic, ethnobotanical and horticultural importance: a checklist. Kew Bulletin, 56, 257-360.

Simpson, D. A., Muasya, A. M., Chayamarit, K. et al. (2005). Khaosokia caricoides, a new genus and species of Cyperaceae from Thailand. Botanical Journal of the Linnean Society, 149, 357-364.

Simpson, D. A., Muasya, A. M., Alves, M. et al. (2007). Phylogeny of Cyperaceae based on DNA sequence data: a new rbcL analysis. Aliso, 23, 72-83.

Smith, S. Y., Collinson, M. E., Simpson, D. A. et al. (2009). Elucidating the affinities and habitat of ancient, widespread Cyperaceae: Volkeria messelensis gen. et sp. nov., a fossil mapanioid sedge from the Eocene of Europe. American Journal of Botany, 96, 1581-1593.

Soros, C. L. and Bruhl, J. J. (2000). Multiple evolutionary origins of $\mathrm{C}_{4}$ photosynthesis in the Cyperaceae. In Monocots: Systematics and Evolution, ed. K. L. Wilson and D. Morrison. Melbourne: CSIRO Publishing, pp. 629-636.

Takahashi, H. G., Yoshikane, T., Hara, M. and Yasunari, T. (2008). High-resolution regional climate simulations of the long-term decrease in September rainfall over Indochina. Atmospheric Science Letters, 10, 14-18.

Tanner, C. C. (1996). Plants for constructed wetland treatment systems: a comparison of the growth and nutrient uptake of eight emergent species. Ecological Engineering, 7, 59-83.

Terry, P. J. (2001). The Cyperaceae: still the world's worst weeds? In The World's Worst Weeds, ed. C. R. Riches. Symposium Proceedings No. 77. Farnham: British Crop Protection Council, pp. 3-18.

Tuor, F. A. and Froud-Williams, R. J. (2002). Interaction between purple nutsedge, maize and soybean. International Journal of Pest Management, 48, 65-71.

Väre, H. and Kukkonen, I. (2005). Seven new species of Cyperus (Cyperaceae) section Arenarii and one new combination and typification. Annales Botanici Fennici, 42, 473-483.

Willis, F., Moat, J. and Paton, A. (2003). Defining a role for herbarium data in Red List assessments: a case study of Plectranthus from eastern and southern tropical Africa. Biodiversity and Conservation, 12, 1537-1552.

WWF (2008). Climate Change Impacts in Krabi Province, Thailand. Bangkok: WWF and SEA-START. http://assets.panda.org/downloads/ thailand_full_final_report.pdf.

Yesson, C. and Culham, A. (2006). A phyloclimatic study of Cyclamen. BMC Evolutionary Biology, 6, 72.

Yusuf, A. A. and Francisco, H. A. (2009). Climate Change Vulnerability Mapping for Southeast Asia. Singapore: Economy and Environment Program for Southeast Asia. 